\title{
TECHNOLOGICAL SOCIETY: PROMOTION AND PROTECTION OF HUMAN RIGHTS*
}

\author{
SOCIEDADE TECNOLÓGICA: PROMOÇÃO E PROTEÇÃO DOS \\ DIREITOS HUMANOS
}

\author{
Gabrielle Bezerra Sales Sarlet \\ Carlos Alberto Molinaro
}

\begin{abstract}
The most striking feature of the contemporary world is that technology has built an absorbing ambiance whose boundaries mark the survival of humankind. In this sense, the technique involves much more than the multiplicity of artifacts produced and entangles us in desires of consumption, in predetermined needs, for it is not revealed only in a matter of objects in the hands of people. It acquires a particular contour building a very complex network in which our daily lives are incorporate. Thus, the systemic character of contemporary technology confronts us with new and innovative issues, also requiring new and creative dimensions of individual and social responsibility. Law and science are among the primary sources of prestige and power in modern societies, as well as the institutional environment and politics. Law (in the broadest sense of legal order) is the primary virtue of social institutions because it regulates relations between people, including facts. Science, in turn, allows us to discover the world around us and question us. Also, political power and administration provide the necessary subsidies to understand the scientific and technical claims that seek the maximum advantage for specific groups of society, or sometimes for society as a whole. Here we intend to collect some ideas that confront our way of perceiving the politics, economy, and law to debate the need to update the law. The method employed is exploratory by literature review, using the inductive method for observation of phenomena, as well as for the discovery of the relationship between them and generalization of this relationship.
\end{abstract}

Keywords: Human Rights. Technology. Power. 


\section{RESUMO}

A característica mais marcante do mundo contemporâneo é que a tecnologia construiu um ambiente absorvente cujos limites marcam a sobrevivência da humanidade. Nesse sentido, a técnica envolve muito mais do que a multiplicidade de artefatos produzidos, nos enreda em desejos de consumo e em necessidades predeterminadas, pois não se revela apenas em uma questão de objetos nas mãos das pessoas. Adquire um contorno particular construindo uma rede muito complexa na qual nossas vidas diárias são incorporadas. Assim, o caráter sistêmico da tecnologia nos confronta com questões inovadoras, exigindo também novas e criativas dimensões de responsabilidade individual e social. 0 direito e a ciência estão entre as principais fontes de prestígio e poder nas sociedades modernas, assim como o ambiente institucional e a política. 0 direito (no sentido amplo de ordem jurídica) é a principal das instituições sociais, porque regula as relações entre as pessoas, inclusive os fatos. A ciência, por sua vez, nos dá a oportunidade de descobrir o mundo ao nosso redor e nos questiona. Além disso, o poder político e a administração fornecem os subsídios necessários para entender as reivindicações científicas e técnicas que buscam o máximo de vantagens para grupos específicos da sociedade, ou às vezes para a sociedade como um todo. Aqui pretendemos colecionar algumas ideias que confrontam nossa maneira de perceber a política, economia e o direito para debater a necessidade de atualizar o direito. A metodologia empregada é a exploratória com a revisão da literatura, utilizando-se o método indutivo para a observação dos fenômenos, bem como para a descoberta da relação entre eles e generalização dessa relação.

Palavras-chave: Direitos humanos. Tecnologia. Poder.

\section{INTRODUCTION}

The advent of the information society has caused a significant change in our understanding of personal and social work in our daily lives. The constant changes that occur in the context of the economic, technological and, above all, globalized environment, contribute to the creation of a new social scene, highlighting new forms of communication, information displacement and new standards and values of life.

The advent of the information society has caused a significant change in our understanding of personal and social work in our daily lives. The constant changes that occur in the context of the economic, technological, 
and, above all, globalized environment contribute to the creation of a new social scene, highlighting new forms of communication, information displacement, and new standards and values of life.

The terms "information society" or "knowledge economy" are now firmly incorporated into the everyday vocabulary, the frequent use of such expressions in the media, strategic documents, and operational programs of societies (not only regional but also national and supranational). Therefore, they can no longer be doubted by the reader (spectator, or participant), since they are included in them almost every time they come into contact with some form of media or media behavior. However, none of the terms defined clearly and transparently about the current sociocultural and sociopolitical development of these same societies, of these same readers, which in part can contribute to a change in their meanings ${ }^{1}$.

Regarding importance, it is evident that emphasizing the information and knowledge algorithm when linked to the terms company or economy suggest socio-political changes under the influence of many factors, notably with the environment in which business and economics take shape. The second half of the last century (the 1950s and 1960s respectively) implied the existence of a historical context marked by a period of significant change, which Drucker (1969) called a period of discontinuity, these significant changes were initiated and, have significantly influenced the development of scientific and technological progress. For this reason, since the 1970s, there has been a persistent turbulent environment, that is, a metaphorical expression for environments identified by its fluidity and requiring individuals of companies (or institutions in any form) a rapid and constant adaptation.

In the 90 s of the 20th century, we find in literature the term "new economy" that was appropriately designated to distinguish the main characteristics intrinsic to the current development of the economy. During this period, there were also some fundamental changes in the approach to what called human capital. Concepts, which emphasize human resources as well as their qualifications, are drawn, there is a noticeable and evident change in the preferences of economic wealth for social and cultural capital (from strategic resources for human resources). 
As Senge (2008) notes, the notion of a learning organization, where people continually expand their capacity to create the results they truly desire, where new and expansive thought patterns nourished, emerges. Senge (2008) emphasized set free and where people are continually learning to see the whole together (p.3). Changing preferences to provide further meaning to human capital is likely to lead to a gradual fusion of the term's information society and knowledge society. Thus, some changes can be felt in the terminology: the knowledge-based economy. In which knowledge perceived as a tool rather than a product. In both cases, the interdisciplinary approach influenced by many economists, computer scientists, system engineers, and others, as well as jurists, sociologists, psychologists, and, ultimately, notably, cognitive scientists.

\section{TECHNOLOGY AND CONCENTRATION OF POWER}

These include: (a) being able to see what is happening through the development and analysis of statistical information; and (b) a political, economic, and social analysis to propose and implement appropriate policies that lead to growth and prosperity maxims.

While many studies show that rapid investment in Information and Communication Technology (ICT) has been and still is responsible for the dramatic increase in productivity rates, this phenomenon should not be presumed to be the result of an increase in exogenous innovation and potential of the ICT sector. Much of this innovation has been and still is due to the environment of active economic competition in the less regulated and more open international markets, which allows the entry of entrepreneurs with innovative ideas, especially linked with efficient operators. Within such an environment, the demand for ICT innovation created (almost permanently), and, at the same time, it induces innovations in the use of these new technologies. Thus, a correct policy must point to the existence of adequate conditions of gestation in the ICT sector and the whole economy in the context of competition, as well as, mainly, the correction of possible market failures ${ }^{2}$. 
However, some problems arise; however, some issues result, mainly when we base the mechanisms of innovation and the character of technoscience as democratic or oligarchic, pending the extent to which citizens can exercise control over its contents. If we accept the premise that techno-science is neither neutral nor independent and that its nature decisively determined by the power relations arising from the existing legal framework and intertwined with this dominant social paradigm, we can assume that techno-science does not is democratic. The high degree of concentration of power that characterizes present-day society implies an oligarchic control over techno-science whose content, in turn, reflects current power relations and the dominant social paradigm.

The concentration of wealth of some who control the economics process for a market economy was the inevitable result of the pursuit of profit, maximizing economic efficiency and defining the market size at every moment, since, as numerous studies suggest (Martin, (Kauffman \& Kumar, 2007; Glenn et al., 2010) there is a robust and encouraging correlation between industrial effectiveness and market concentration. We have an indication here that the pursuit of profit by those who control the market economy leads to strength. In the initial phase of commodification, the concentration of economic power was the result of mass production. The concentration of the production process in dimensioned production units guaranteed the so-called economies of scale and also economic efficiency.

Today we see an opposite phenomenon. Now capitalist firms, to survive competition, in an internationalized market economy are forced to produce smaller quantities of products with high-quality specifications, thus removing economies of scale from their position in the central dynamics of competition (Langlois, 2007; Lall, 2005; Chandler, 2004). The so-called economies of scope produce wealth; therefore, the concentration of economic power coincides today with a parallel process of de-massification of production and diversification, which is consistent with the demands of modern post-industrial and technological society - however, this de-massification in output affecting the size of the plant. Moreover, the number of jobs has no effect on the extent of the concentration of economic power at the enterprise level. Here it is 
evident, for example, that 500 largest multinationals now control twothirds of world trade; and that all these companies (except some Asian ones) have their matrix on North (taken "North" in the economic sense, and not geographic) ${ }^{3}$.

The concentration of economic power is indeed not a new phenomenon. In any hierarchical society, the concentration of wealth has always accompanied the concentration of political and military power in the hands of the few, usually justified by a system of social norms based on religion (Benevides \& Dali, 1989). The new element in growth economies is the fact that today the reproduction of the social system itself, and the power of few to control it, crucially depends on the attainment of the development objective, which in turn is justified by identification progress, development, and well-being. Therefore, the functions of economic growth, not only as a fundamental social and economic goal but also as an essential means to reproduce the structures of unequal distribution of economic and political power that characterize the modern hierarchical society, as well as a central element of ideology which supports it. The hierarchical community has taken a new shape with the rise of the market economy in the West. Moreover, the planned economy in the East. In this new form, the elite withdraw its strength not only, as before, by the concentration of politicians, military, and businesspeople, but mainly by the intensity of economic power.

The current concentration of economic, political, and social power in the hands of the few that control the economy is not only a cultural phenomenon that can be explained by the values established by the industrial revolution. Indeed, concentration of power is the inevitable result of a historical process that began with the prevalence of hierarchical social structures and the implicit ideology of man's domination over man, and especially of nature, peaking in the last two centuries, with the development of the market economy, and its branch, the growth economy (Foley \& Michl, 1999; Foley \& Model, 2003; Dennison \& Ogilvie, 2016). Market economy/growth and concentration of economic power are two sides of the same coin. This fact demonstrates that neither the level of economic power nor the ecological implications of the growth economy can be neglect in the scenario of the current institutional framework 
of the market economy / internationalized growth. On the other hand, however, the increase in the concentration of economic power leads to the conclusion that the idea of development does not mean, in most cases, an improvement in the quality of well-being through growth, since development and growth are entities several that may coincide ${ }^{4}$.

\section{TECHNOLOGY, DEMOCRACY, AND THE INDIVIDUAL}

The recent eighteen years of this century have revealed remarkable advances in communications and information technology, including digitization, video platforms, smartphones, social media, billions of people with Internet access, and other notable acquisitions. These revolutionary transformations imply (and increasingly will be the implications) a renewed empowerment of individuals as they gain greater access to information, ease of communication and data sharing, and more various technological tools (Lakshear \& Knobel, 2008). However, despite these changes, we are unable to achieve equitable development in our political systems. We all know that democracy is a political system supported by the idea of empowering individuals, strengthening citizenship, and the fullness of human and fundamental rights. However, in these same years, we can observe that democracy is stagnant in several latitudes of the planet. In this sense, some critical observations need clarification.

Regardless of the concentration of technological power in the hands of someone, and the centralization of political power, the nature of the technology that will be enclosed and incorporate a democratic society does not depend only on who owns, or even who controls it. Sufficient condition always depends on the value system that democratic society adopts, as well as the level of awareness of its citizens. Any change in the institutional, technological, and democratic framework depends on education, which is not merely instruction, but the development of character, skills, and abilities in acquiring knowledge, nationally and internationally. The culture of the individual as a citizen will play a crucial role in shaping this new system of socio-cultural and economic values 
necessary to raise the level of global social consciousness (Lakshear \& Knobel, 2008).

Marx (1981) believed that humanity would move from the realm of necessity to the field of freedom through the rational and socially responsible application of advanced technology created by capitalism (p.959). However, technology itself does not have an inherent ability to flow a liberating society in the sense that it reduces human labor by inducing the path from the realm of necessity to the field of freedom. The essence of a liberating technology is not the real character, but of the subjective sense embodied in a democratic society. Technological progress has not diminished human effort. Where the labor market is free, its actors go to work even more (!), A simple internet search gives us the indication that the technology itself is not responsible for reducing or increasing the amount of work, socioeconomic organization.

High technology can be both liberating and oppressive, and not only by its user, but owing to the power relations stemming from socioeconomic institutions, as well as the corresponding dominant social paradigm. What determines the character of a liberating democratic technology will be the by product of a new liberating project, and such a project does not require a post-scarcity society (Sadler, 2010). The idea that a liberating technology could only found on a post-scarcity society involves a sense of progress that is incompatible with the democratic principle that there are no laws (social and natural) that determine social change, which is only achieved by historical experience.

From a democratic perspective, the distinction between a technology for the realm of need (society of scarcity) and another for the kingdom of freedom (post-scarcity society) makes no sense, since post-scarcity society is merely a myth, especially if we take into account the ecological limitations of economic growth (Chernomas, 1984).

The individual almost always has the opportunity to participate with society in the formulation and dissemination of impressions, ideas, beliefs, judgments, desires, and interests, which society as a whole becomes aware of and gradually incorporates to flow new situations of communication and, even of assumption of this island characteristic. Nowadays, the communication society has gone too far, getting to 
transform the dialogue a different phenomenon that affects this same information, implying an enormous impact on human beings. A person can quickly change his way of thinking or, more seriously, break his attitude by saying something today and tomorrow to agree to something once, and then very close, to disagree, pending the insinuations and the atmosphere of talk that finds in the networks.

On the other hand, the change of society, as identity and permanence, has always been slower and more difficult. However, today, this happens much more quickly due to technological progress, not only in the media scenario but mainly in the ambiance of the Internet accessed directly by billions of people simultaneously. However, all this information has no root identifiable or identifiable mark, so we cannot rely on finding a real connection with people's lives, because this communication, sometimes barren, is relayed merely without any genuinely personal experience. The phenomenon that makes the cohesion of human communication disappear and with it dazzle different moral values.

There is a difference between ideas and beliefs. An idea is a thought, something questionable and debatable. Belief is something that raises questions because it is a matter of faith and represents the feelings of the individual. Thus, while previously, a fraction of information had a cognitive and practical meaning today, they can be easily directed and manipulated to serve interests based on speculative motives. These ideas and beliefs, some of which are transmitted by the media, can be used to manage and guide the exercise of power at a time when the individual is more vulnerable.

Nowadays everyone can talk about the same subject at the same time, and on a global level, they can do it to suppress some information to impose, even a universal silence. So, no one talks globally about something that might interest people around the world. Thus, this situation architects a new form of totalitarianism, not only the power of the state but a totalitarian, global power of speech. However, the most striking thing is that we have cultivated an entire political spirit of what is considered essential and worthy of our attention. It seems that nothing is irrelevant and that everything must be manipulated, tested and, if necessary, one can immediately carry out the most 
different interventions; this, previously, occurred in countries governed by totalitarian regimes, but now happens in politically free societies, leading to the loss of human freedom and spontaneity.

Therefore, we see that the media can have a severe impact on the social fabric and contribute to the permanent loss of the privacy and privacy of an individual. Today everything can be recorded; individuals can spy on each other with great ease even without legitimate interest. The result is the feeling of being at the mercy of events and the speed of information, occasional, and diatopic.

\section{TECHNOLOGY AND ECONOMY}

It is still little understood, due to insufficient inquiries, that the digital economy in marked aspects contrasts with the industrial economy. Some guidelines that should guide an agenda for the promotion and protection of human rights and fundamental rights in public orders: The Digital Economy and its services represent an increasing part of value creation in the global economy; Only the first digital device requires capital, infrastructure, and work. The following copies are virtually free of cost; this means unproductive profit, which means that the need for labor is practically gone; Digital products and services are almost free of transportation costs, including global transportation; this means that, eventually, the best outcome distributed in the worldwide market and the national digital product markets diminish the global; For some applications it is required that they become a significantly better product, and so the people who use them will start to use them more, which increases their functionality, based on data provided by the users themselves; this induces that in a global digital market is not a market for the second-best product because the winner takes it all; A part of the emerging digital economy is an exchange economy, which ignores the formal economy; Digital economy and automation eliminate more jobs than they create, and now also include so-called white-collar jobs (doctors, teachers, and lawyers) and not so-called blue-collar jobs (factory work and farm labor); On the other hand, digital technologies create a 
large number of posts for the most qualified, skilled, and qualified for S \& T where these people can allocate "price" (to wages) in the global labor market to a large extent. One example is to develop or deploy new digital products and Alphabet, Google, Microsoft, and Apple services, as well as several companies in the same area, whether public or private; Scanning costs jobs; For the rest of the labor market, it looks considerably different; As digitization eliminates more jobs than it creates, we must focus on how, through other channels, we can stimulate the creation of a more inclusive society and a different kind of economy. If not, we fear that there will be more unemployed and impoverished workers, that is, people who work full time without being able to get out of poverty; There will be fewer and fewer middle and lower jobs, and therefore a growing supply of internationally redundant labor, which will result in lower wages and more extended working hours at the bottom of the labor market, generating economic and social uncertainties; Scanning is not only undermining the known production and communication methods but also the tools we have to compose and plan political, economic, and investment decisions.

Taking this into account, we should note that phenomena as diverse as democracy, rule of law, human rights, market economy, capitalism, money creation, banks, trade union movement, unemployment insurance funds, welfare state, national sentiment, the right-left political spectrum, and even our schools and local communities are products of the industrial age, its technologies, and its capital structure. As individuals, we have learned to navigate the industrial economy and navigate the most complex intricacies of society; we have approximately been able to control and define policy and law (the law and the accumulation of capital). However, few dare to imagine how the digital global economy will look, or how institutions and structures will develop, and what we will have to conceive to create free, secure, and stable societies.

Unlike the transition from agrarian and industrial society, the transition to tomorrow's economy does not take 100 years, but possibly only a generation. Following the standards in the transition to the global digital economy, we can observe: It serves more for wealth than labor effort, as the return on investment is higher than the value of labor, 
keeping the middle class under increasing pressure; When the work is digitized, streamlined, and automated, it becomes increasingly difficult for the middle class, and less and less the ability to provide the tax revenue needed to ensure the nation's operation; The global economic network increasingly geared towards the economy of scope; this means that the worldwide dealer network is increasingly becoming free of economies of scale; Economic interest groups assume increasing political power, and what can see is that democracy collapses as political power increasingly focuses on fewer hands; Multinational corporations, governments, and various intelligence services frequently take advantage of digital infrastructure to gain access to private data of individuals and institutions, compromising the security of nation-states, societies, citizens, freedoms, and human rights and the fundamental democratic ones; As the French economist Thomas Piketty (2014) has documented, there is a higher return on speculation than on labor. This engine of economic inequality further aggravated when the middle-class workforce disappears in rich countries because of digitization and automation.

It is worth remembering that it is some particular technologies that define power structures, monitoring options as well as economic interests that permeate, or will fill, all aspects of our lives. Two elements of this new infrastructure can have severe consequences if you make the wrong decisions now. The first question is whether the systems built are the correct ones and whether they based on our freedoms as citizens of a democratic society or whether they based on short-term economic interests and the political interests of power? The second question is whether the solutions are technically feasible in the long term concerning the parties. Are they flexible and adaptable? Can they be easily adapted to rapid technological change, and us as human beings and citizens?

\section{TECHNOLOGY, NATION-STATE, AND RISK}

The nation-state as we know it is in crisis and a speedy way of overcoming it. It was/is a product of the industrial era, as well as its methods of production, transportation, work, and communication. Our 
political and economic power, our social structures, institutions, and legislation are products of the industrial age. Our status as subjects of law, our civil, fundamental and human rights, our democracy and our freedoms are the products of industrialized nation-states.

Production processes and the economy have changed as a result of digitization. Described as a digital economy is fundamentally different from the industrial one. One consequence of this is that the national sovereignty of states is/remains impaired. All countries are in confront with the problem; no state can avoid it. Global digital connectivity means global dependency, and no nation can meet the challenges of technological development and innovation in isolation.

Besides, there are the following problems to solve: Local consumption creates global warming. The Environment is worldwide, and as a species, we urgently need the sustainable use of the planet's resources; The waste of a carbon economy contaminates, and the contamination does not obey the geopolitical borders; The world is expected to reach 9 billion by 2050 . At the same time, there will be more significant migration and challenges related to socio-cultural and economic problems; As the world "shrinks" becomes shorter by shortening distances and customs, it becomes more challenging to reconcile radically different economies, cultures, and forms of government, and lead them to cooperate. If the levels of complexity between them do not match and do not match, we have a big problem there; There is no free movement of information (and therefore of products), labor, and capital across national boundaries. The world is changing more and more. Of approximately 200 national economies in a single global economy, for which there are no universal rules or legal certainty. At the individual level, everyone participates in a global job market; National economies are communicating vessels to determine prices, wages, and labor standards; Companies move to places where they do not have to pay taxes. Nation-states are competing with each other to offer the lowest fees, which compromises their sovereignty; There are no global, legal or other structures established to manage this transformation, nor do we have the fundamental economic theories, or models to deal with the problems, let alone the statistical data to describe the development and its impact. 
Without an understanding of the structural changes that technological development takes our economy and society globally, politics becomes useless. To guarantee the future of citizens of nationstates is necessary to understand national policies in various areas belong to the past. Sovereign states may, of course, have a future as geographical, cultural, and linguistic areas, but we as citizens need to understand that the nation-state as we know it will not continue to exist. We need to work together on larger units and give up some forms of sovereignty if we are to maintain the balance and sustainability of existence. The nationstate must be redefined more appropriately, considering desires and possibilities of well-being, and wealth and education fluidity, but needs to adapt to the new technological conditions. If we continue to believe that we can compete with other nation-states, just as industrial enterprises compete with each other, states will be racing into the obscurity. In the long run, this will mean increasing inequality in the society where few have everything, and where many have almost nothing (better think, perhaps, of nation-states, multi-polar and inclusive).

We urgently need to encourage collaboration on agreements on international rules. International legal cooperation is necessary for the long-term to achieve an improvement in the lives of global and national communities. Unfortunately, it is difficult to follow this political discussion without accessible education, and the undemocratic debate of pressure groups (and even the phenomenon of global terrorism) lessens the likelihood of further progress. Challenges such as global warming, refugees or displaced people, and cross-border pollution can also only resolve through international cooperation.

We must admit in the future that staying as a nation-state faced with intense globalization, with the concentration of many' interests against those of a few, is a big challenge. From the fully digitalized global reality, we need to think differently and understand the world as it is, not as it was. We need new stories; we need the speed shift driven by technology to make sense. 


\section{FINAL REMARKS}

As a result of technological development, the old narratives are not enough. In a globalized world, factors such as migration and communication around the world come from religious narratives mapping an extent in which they claim to have exclusivity over the truth. In a globalized world, with the interdependence of national tales, the creation of universals is not expected. The political axis between right and left used to be about participation and social cohesion. Now it is mostly about feelings and value politics. Right and left arose from industrial society as well as the class struggle between employers and employees.

The scenario has changed. In the Western world, there is the whole political spectrum today of a broad consensus on open society, liberal democracy, the market economy, and a certain degree of public welfare. There may be disagreement about - for example - taxation or parts of welfare services, but generally, there is a consensus about the model. The result is that voters are organized based on some other criteria. Political parties seek to attract members and voters of both economic interests and similar emotional and psychological needs.

Postmodern deconstruction has reduced science to a report on an equal footing with other narratives, and deconstruction rejects the scientific concept of truth to such an extent that it has made it very difficult for individuals in two different cultures to communicate. As a result, ancient narratives like religion, nation, and class lose their explanatory power and revive totalitarian forms. The only significant story that has survived is the market to meet consumer demand and to be able to produce goods efficiently. However, it cannot solve any of the above challenges. On the contrary, it makes mercantilization or commodification only fuel to ignite the fire of nonconformity.

The digital economy has implications for the basic structure of our society. If we want to maintain sustainable economies, human dignity, human rights, democracy, and social stability, we must face the widespread impact of digitalization on national and international policies. Original and dangerous for the nation-state is the idea of the free, unconditional market concerning social responsibility. 
We can make the most of technological possibilities on the premise that all of us, individuals, politicians, and the media, begin to agree and take an interest in ongoing global development. There is no point in trying to displace it, even if the context seems complicated and confusing. Alternatively, we take responsibility for ourselves and choose to use technologies at their best, or we must be subordinate to them and to those who trap them in their interests.

We need guidelines for the promotion and protection of human rights, and especially for broadening the spectrum of the effectiveness of the fundamental rights of national states. We must bear in mind that contemporary society immersed in profound transformations that substantively alter meanings and the imaginary, individual, and collective.

In this scenario, social phenomena reproduce violence, with the displacement of vast human collectives from qualified social convivence. The disquiet that is produced by exclusion and seclusion (in social marginality) proves to be an inducer of deterioration of the quality of life and organizes the construction of subjectivities marked by misery in its most diverse manifestations. It is a serious problem and does not concern access to justice for the excluded, but rather their non-participation in it.

The difficulty of access to justice is not only due to the scarcity of resources, normative adequacy, etc., it is more profound, it is a problem that involves the paradigms of rationality of the law (legal reason), of its ideology in addition to the roles that represent those who participate in the legal activity. Consequently, we need to confront the standard upon which the discourse and practice of law rest. Therefore, necessary to think of a new right - a critical and technologically supported right whose production depends on the needs of the people - concrete people, existential needs that demand real satisfaction. Beyond the law, the legal address is the satisfaction of marginalized private interests (which are collective) and not the letter of the norm.

A critical right that thinks a real justice must aim at occupying a space of significant transforming potentiality: the social movements of all species, including those activities allocated in the third sector. It is in this space where the empowerment may be fruition from a sociopolitical and legal perspective of the construction and integration of identity and 


\section{citizenship. The technology can help in increasing the speed of production of the norm and its execution. Symmetrizing the times of social life and that of the creation of social justice.}

\section{NOTAS}

1 It is worth noting that with the development of new technologies in several areas, there has been a change in the articulation of information in the mass media, especially in the digital environment (Rogers, 1986; DeFleur \& Dennis, 2010; Bennet, 2003; Davis, 1999). These new means of transmitting information, to some extent, influence our perception of daily events nationally or internationally. In the recent past, those who decided what should or should not broadcast through the media were those who, in one form or another, held power, that is, political groups, TV producers or media tycoons (who still are out multiplying information and counter-information). However, the current alternative, so-called new media has shown that anyone can express their discontent, dissent, or support for a particular cause. Anyone can lead a movement in the digital world using new technologies. Some of the most popular new media are blogs and social networking sites where anyone can create their platform to express their opinions (Stăiculescu; Nădrag, 2015, p. 406).

2 See, Stehr (2005), stating that a new field of political activity is emerging in democratic and modern societies, aimed at regulating the development and use of new scientific and technical knowledge. The focus is on the new technologies developed over the last forty years, which include the human design test tube, reproductive cloning, genetically modified food, genetic engineering, etc. Controversies and public debates on the use of these new scientific and technical knowledge points for the need to find ways to directly control and regulate their immediate use in an attempt to anticipate the consequences in advance.

3 For further discussion, see the classic work of Lang \& Hines (1993), The New Protectionism: Protecting the Future Against Free Trade, where the authors question the benefits of free trade, arguing that: far from promoting prosperity for all concerned, free trade serves only a narrow range of interests, especially for large companies. The authors say that the consequences of current provisions will increase the gap between the rich and the poor. As well as induce the acceleration of the destruction of the global environment. They suggest that, instead of trade agreements, regional self-sufficiency should emphasize, just as the overall amount of trade should reduce.

4 See, Gwartney et al. (1999); Acemoglu, (2008); Haller (2012); Aghion (2016). 


\section{REFERENCES}

ACEMOGLU, Daron. Introduction to Modern Economic Growth. Princeton N.J.: Princeton University Press, 2008

AGHION, Philippe. Some "Schumpeterian" Thoughts on Growth and Development. Paper. Worldbank.Org. May 2016. In: http://zip.net/bjtspC

ALI, Ashiq; KLASA, Sandy; YEUNG, P. Eric. The Limitations of Industry Concentration Measures Constructed with Compustat Data: Implications for Finance Research (Feb/2008). In SSRN: http://ssrn.com/abstract=926269

BENNETT, W.L. New media power: the internet and global activism, in COULDRY, N. and CURRAN, J. (eds). Contesting Media Power. New York: Rowman and Littlefield, 2003.

BROWN, John Seely. Growing Up Digital: How the Web Changes Work, Education, and the Ways People Learn. www.johnseelybrown.com, 2000. In: http://www. johnseelybrown.com/Growing_up_digital.pdf

CHANDLER, Jr., Alfred D. Scale and Scope: The Dynamics of Industrial Capitalism. 7th Imprint. Cambridge/MA: The Belknap Press of Harvard University Press, 2004 ,

CHERNOMAS, Robert. Keynes on Post-Scarcity Society. Journal of Economic Issues. Vol. 18, 4 (Dec 1984), pp. 1007-1026. Sistema pay-per-view): http:// zip.net/bftspd

DAVIS, D. Media as public arena: reconceptualizing the role of media for a post-cold war and postmodern world, in VINCENT, R., NORDENSTRENG, K. and TRABER, M. (eds). Towards equity in global communication, Cresskill/N.J.: Hampton Press, 1999.

DeFLEUR, Everette E.; DENNIS, Melvin L. Understanding media in the digital age: connections for communication, society, and culture. New York: Allyn \& Bacon, 2010. 
DENNISON, Tracy K.; OGILVIE, Sheilagh. Institutions, Demography, and Economic Growth. The Journal of Economic History, Vol. 76, No. 1 (March 2016). In: http://zip.net/bqttp2

DRUCKER, Peter. The Age of Discontinuity: Guidelines to Our Changing Society. New York: Harper and Row, 1969.

FOLEY, Duncan K.; MICHL, Thomas R. Growth and Distribution. Cambridge/ MA: Harvard University Press, 1999.

FOLEY, Duncan K.; MODEL, Leo. Unholy Trinity: Labor, Capital and Land in the New Economy. New York: Routledge, 2003

GLENN, Ellison; GLAESER, Edward; KERR, William. What Causes Industry Agglomeration? Evidence from Conglomeration Patterns. American Economic Review, 2010, 100(3): 1195-1213. In: http://zip.net/bpts0W

GWARTNEY, James, LAWSON, Robert, \& HOLCOMBE, Randall. Economic freedom and the environment for economic growth. Journal of Institutional and Theoretical Economics, 1999, 4, 643-663. In: http://zip.net/bdtsTM

HALLER, Alina-Petronela. Concepts of Economic Growth and Development. Challenges of Crisis and of Knowledge. Economy Transdisciplinary Cognition. Vol. 15, Issue 1/2012 p.66-71. In: http://zip.net/bwtrVG

KAUFFMAN, Robert; KUMAR, Ajay. The New Economic Geography of IT Industries: The Impacts of the Internet on their Market Linkages and Agglomeration. ICIS 2007 Proceedings. Paper 37. In: http://aisel.aisnet.org/ icis $2007 / 37$

LAKSHEAR. Colin; KNOBEL, Michael. Introduction: Digital Literacies - Concepts, Policies and Practices. Digital Literacies Concepts, Policy and Practice. Colin, Lakshear \& Michael Knobel (eds.). New York: Peter Lang, 2008.

LALL, Sanjaya. Rethinking industrial strategy: The role of the state in the face of globalization. In Gallagher, K. (ed.). Putting development first: The importance of policy space in the WTO and IFIs. London and New York: ZED Books, 2005, pp. 33-68. 
LANG, Tim; HINES, Colin. The New Protectionism: Protecting the Future Against Free Trade. London: Earthscan, 1993.

LANGLOIS, Richard N. The Dynamics of Industrial Capitalism: Schumpeter, Chandler, and the New Economy. London: Routledge, 2007.

MARTIN, Stephen H. Advanced Industrial Economics. Second Edition. London: Blackwell, 2002.

MARX, Karl. Capital. Vol. III. New York: Penguin. 1981

NICOLAI, Georg Friedrich. Die Biologie des Krieges. Zürich: Art. Institut Orell Füssli, 1919. Reimpressão, Universidade de Michigan, 2008.

PIKETTY, Thomas. Capital in the Twenty-First Century. Cambridge/MA: Harvard Univ. Press, 2014.

PONTES DE MIRANDA, Francisco C. Sistema de Ciência Positiva do Direito. tomo I, 2.a ed., Editor Borsoi, Rio de Janeiro, 1972.

ROGERS, Everett M. Communication Technology: The New Media in Society. New York: The Free Press, 1986.

SADLER, Philip. Sustainable Growth in a Post-Scarcity World: Consumption, Demand, and the Poverty Penalty. Surrey/England: Gower Applied Business Research, 2010.

SENGE, Peter. The Fifth Discipline: The Art \& Practice of The Learning Organization. New York: Crown Publishing Group, 2010.

SENGE, Peter; SCHARMER, Otto; JAWORSKI, Joseph; FLOWERS, Betty Sue. Presence: Human Purpose and the Field of the Future. New York: Crown Business (Reprint edition), 2008.

STĂICULESCU, Ana Rodica; NĂDRAG, Monica. The Impact of New Media on Society. Sociology, Political Sciences, International Relations. Romania: GIDNI 2 - Globalization, Intercultural Dialogue and National Identity. Second edition. 2015. In: http://zip.net/bgtsjG 
STEHR, Nico. Knowledge Politics: Governing the Consequences of Science and Technology. Paradigm Publishers, 2005.

Recebido em: 18-12-2019

Aprovado em: 19-12-2019

\section{Gabrielle Bezerra Sales Sarlet}

Pós-doutora em Direito pela Universidade de Hamburg, Alemanha; pósdoutoranda em Direito pela PUC/RS; doutora em Direito pela Universidade de Augsburg, Alemanha; ex-bolsista do MPI- Instituto Max Planck Hamburg (Alemanha); professora do curso de graduação em Direito da Universidade Feevale(RS); advogada. E-mail: gabriellebezerrasales@gmail.com

\section{Carlos Alberto Molinaro}

Doutor em Direito, summa cum laude, com acreditação de "Doctor Europeo"' (DERECHOS HUMANOS \& DESARROLLO 2a. Edición) - Universidad Pablo de Olavide; revalidado em 2007 pela Universidade Federal de Santa Catarina; professor na graduação, especialização, mestrado e doutorado, da Faculdade de Direito da PUC/RS; pesquisador do NEDEF-PUCRS. E-mail: molinaro@ camolinaro.net

Pontifícia Universidade Católica do Rio Grande do Sul

Av. Ipiranga, 6681 - Partenon, Porto Alegre - RS, 90619-900 
